\title{
PESANTREN SAINS: Epistemology of Islamic Science in Teaching System
}

\author{
Mohamad Yasin Yusuf \\ Universitas Islam Negeri (UIN) Sunan Kalijaga, Yogyakarta \\ e-mail: mohamadyasinyusuf@ymail.com
}

\begin{abstract}
Muslims around the world mostly was under the domination of the West in the mastery of science and technology. Establishing educational institutions that are based on science and technology is one of the ways to solve the problem.This study had the purpose to examine the epistemology of science in the teaching system in SMA Trensains boarding school Tebuireng Jombang. Applying the method of field research through qualitative approach and philosophical analyses, this study revealed that SMA Trensains Tebuireng Jombang applied "Islamic Science" in which science is constructed based on the revelation of God. It is meant that in Islamic epistemology, revelation and the Sunnah are the sources which are inspiring for building sciences. It is hoped that the building the Islamic epistemology of science will bear pious Muslim generation in religious field and proficient in science and technology, and it will impact to the glory of Islamic civilization in the future.
\end{abstract}

Pada umumnya, umat Islam di dunia ini berada di bawah dominasi Barat dalam penguasaan ilmu dan teknologi. Pendirian lembaga pendidikan yang didasarkan pada ilmu dan teknologi merupakan salah satu cara untuk mengatasi masalah tersebut. Kajian ini bertujuan untuk meneliti epistemologi ilmu dalam sistem pengajaran di SMA Trensains di pondok Pesantren Tebuireng Jombang. Dengan menggunakan metode penelitian lapangan dan dengan pendekatan penelitian kualitatif serta analisis filosofis, kajian ini menemukan bahwa SMA Trensains Tebuireng Jombang menerapkan Sains Islam, di mana ilmu dibangun berdasar wahyu Tuhan. Maksudnya adalah bahwa dalam epistemologi Islam wahyu dan sunnah adalah sumber yang memberikan inspirasi bagi pembangunan ilmu pengetahuan. Diharapkan pembangunan epistemologi Islam untuk ilmu pengetahuan akan melahirkan generasi Muslim yang shalih dalam bidang agama dan ahli dalam bidang ilmu pengetahuan dan teknologi, yang pada gilirannya akan memberikan dampak bagi kejayaan peradaban Islam di masa yang akan datang.

Keywords: epistemology, Islamic science, pesantren sains, Tebuireng, Qur'an, Sunnah 


\section{A. Penduhuluan}

Perkembangan Islam secara massif danintensif di Indonesia baru terlihat pada sekitar abad ke-12 M. dan ke-13 M. melalui para juru dakwah (muballigh) dari kalangan ulama sufi. Penyebaran Islam di Indonesia pertama kali dilakukan di pesisir utara Sumatera (Aceh), karena posisi selat Malaka sebagai jalur perdagangan penting dunia, baru kemudian menyebar ke daerah timur dan utara, seperti Jawa (1450 M.), Kalimantan (1580 M.), Maluku (1490 M.), Sulawesi (1600 M.), Sulu (1450 M.) hingga ke Filipina Selatan (1480 M.). ${ }^{1}$ Menurut Azyumardi Azra, faktor utama yang menunjang keberhasilan islamisasi di Indonesia ini adalah lantaran kemampuan para penyebar Islam yang umumnya para sufi dalam menyajikan kemasan ajaran Islam yang atraktif dan menekankan aspek-aspek keluwesan ajaran Islam khususnya tasawuf dengan mistisisme setempat. ${ }^{2}$

Pada fase selanjutnya, penyebaran dan pendalaman ajaran Islam di Indonesia mulai difokuskan dalam sebuah institusi pendidikan tradisional yang disebut "pesantren". Meski pesantren dalam arti lembaga pendidikan tempat dilakukannya pengajaran tekstual baru muncul pada sekitar abad ke-18, namun berdasarkan catatan sejarah disebutkan bahwa berdirinya pesantren sesungguhnya sudah ada sejak masa-masa awal penyebaran Islam di Indonesia, terutama di Jawa. Tokoh yang pertama kali mendirikan pesantren adalah Maulana Malik Ibrahim (wafat 1419 M.), tokoh Walisongo. Maulana Malik Ibrahim menggunakan masjid dan pesantren untuk pengajaran ilmuilmu agama Islam, yang pada gilirannya melahirkan tokoh-tokoh Walisongo yang juga mendirikan pesantren di wilayahnya masing-masing,seperti Sunan Ampel di Surabaya, Sunan Giri di Gresik, Sunan Bonang di Tuban, Sunan Drajat di Lamongan, dan Raden Fatah di Demak. ${ }^{3}$

Pesantren merupakan institusi pendidikan yang selain mempunyai corak indigenous (keaslian) Indonesia, juga mempunyai corak keislaman. ${ }^{4}$ Latar

\footnotetext{
1Mohamad Kholil, "Menggagas Pesantren sebagai Pusat Peradaban Muslim di Indonesia", Jurnal Media Akademika, Vol. 26, №. 3, Juli 2011, h. 298.

${ }^{2}$ Azyumardi Azra, Jaringan Ulama Timur Tengah dan Kepulauan Nusantara Abad XVII dan XVIII, (Bandung: Mizan, 1998), h. 32-33.

${ }^{3} \mathrm{HS}$. Mastuki dan M. Ishom El-Saha (eds.), Intelektualisme Pesantren:Potret Tokoh dan Cakrawala Pemikiran di Era Pertumbuhan Pesantren, (Jakarta: Diva Pustaka, 2003), h. 8.

${ }^{4}$ Nurcholish Madjid, "Merumuskan Kembali Tujuan Pendidikan Pesantren", dalam M. Dawam Raharjo, Pergulatan Dunia Pesantren: Membangun dari Bawah, (Jakarta: P3M, 1985), h. 3.
} 
belakang kemunculan pesantren adalah untuk mentransmisikan produk pemikiran skolastik Islam tradisional. ${ }^{5}$ Ini berarti pesantren secara genealogis terikat kuat dengan budaya dan tradisi pemikiran Islam abad pertengahan. ${ }^{6}$ Pada abad tersebut, pendidikan Islam secara garis besar berkembang dalam dua aliran, yaitu konservatif dan rasional.7 Pendidikan Islam konservatif yang telah memenangkan percaturan pada waktu itu, secara tidak langsung berpengaruh besar terhadap model dan pelaksanaan pendidikan Islam di era sekarang, termasuk di Indonesia. Bahkan hingga kini masih kuat anggapan dalam masyarakat luas yang mengatakan bahwa "agama"dan "ilmu" adalah dua entitas yang tidak dapat dipertemukan. Pandangan dualisme-dikotomis keilmuan yang seperti itu haruslah di koreksi dan diluruskan, ${ }^{8}$ dengan konsep yang lebih mampu mendialogkan dan mengintegrasikan antara agama dan ilmu pengetahuan umum lainnya. ${ }^{9}$

Dari permasalahan tersebut, maka pesantren perlu segera melakukan "rapprochment", dalam artian kesediaan untuk saling menerima keberadaan yang lain dengan lapang dada, meninggalkan sekat dinding pemisah antara agama dan ilmu pengetahuan, mau saling mendekati, saling menyesuaikan, berdialog dan bahkan berintegrasi antara ilmu-ilmu agama dan ilmu-ilmu umum..$^{10}$ Dan saat ini lembaga pendidikan Islam, khususnya pesantren juga telah berupaya melakukan gerakan "rapprochment".

Hal ini terbukti dengan semakin meningkatnya jumlah institusi pesantren modern maupun campuran, dan terjadi penurunan jumlah institusi pesantren tradisional maupun santrinya. ${ }^{11}$ Bahkan saat ini telah berdiri model pesantren

\footnotetext{
5Martin van Bruinessen, Kitab Kuning: Pesantren dan Tarekat, (Bandung: Mizan, 1999), h. 17.

${ }^{6}$ Mahmud Arif, "Epistemologi Pendidikan Islam: Kajian Atas Nalar Masa Keemasan Islam dan Aplikasinya di Indonesia”, Disertasi, Program Pascasarjana UIN Sunan Kalijaga Yogyakarta, 2006, h. 2727.

7Mahmud Arif, Pendidikan Islam Transformatif, (Yogyakarta: LKiS, 2008), h. 109-110.

${ }^{8}$ Lihat Ian G Barbour, Issues in Science and Religion, (New York: Harper Tourchbooks, 1996), h. 1-2; juga John Polkinghorne, Belief in God in an Age of Science (London: Yale University Press, 1988), hlm. 76100; M. Kamal Hasan, "The Expanding Spiritual-Moral Role of World Religion in the New Millinium”,American Journal of Islamic School Science, Vol. 18, No. 1, Winter 2001,h. 43-58.

${ }^{9}$ Lihat Ian G Barbour, Juru Bicara Tuhan: Antara Sains dan Agama (When Science meets Religion: Enemies, Strangers, or Partners), terj. E. R. Muhammad(Bandung: Penerbit Mizan, 2002), h. 39-46.

10M. Amin Abdullah, "Etika Tauhidik sebagai Dasar Kesatuan Epistemologi Keilmuan Umum dan Agama (dari Paradigma Positivistik-Sekularistik ke arah Teantroposentik-Integralistik)”, dalam M. Amin Abdullah (eds.) Menyatukan Kembali Ilmu-Ilmu Agama dan Umum, Upaya Mempertemukan Epistemologi Islam dan Umum, (Yogyakarta: Sunan Kalijaga Press, 2003), h. 6.

11Suparjo, "Komunikasi Interpersonal Kyai-Santri: Studi tentang Keberlangsungan Tradisi Pesantren di Era Modern", Disertasi, Program Pascasarjana UIN Sunan Kalijaga Yogyakarta, 2012, h. 2-3.
} 
baru yang terkonsentrasi pada pengembangan natural sains dan teknologi. Pesantren ini bernama "Pesantren Sains", disingkat "Trensains", yang dalam sistem pendidikannya menyelenggarakan pendidikan setingkat SMA dengan nama "SMA Trensains". Lembaga ini merupakan sintesis dari pesantren dan sekolah umum bidang sains, dengan kegiatan utamanya mengkaji dan meneliti ayat-ayat semesta yang terkandung dalam al-Qur'an dan al-Hadits. Trensains tidak menggabungkan materi pesantren dan ilmu umum sebagaimana pesantren modern dan kombinasi. Trensains mengambil kekhususan pada pemahaman al-Qur'an dan al-Hadits, sains kealaman (natural science) dan interaksinya. Poin terakhir yaitu interaksi antara agama dan sains merupakan materi khas Trensains dan tidak ada dalam ponpes modern. ${ }^{12}$

Hubungan sains dan agama Islam selama ini memiliki berbagai macam model. Trensains tidak melakukan pendekatan dengan hanya melakukan "Islamisasi Sains", yaitu pembeberan ayat-ayat dengan menggunakan sains yang sudah ada, juga tidak melakukan pendekatan dengan cara "Saintifikasi Islam", yaitu hanya berusaha menjelaskan Islam dengan terminologi sains. Akan tetapi Trensains mengajukan pendekatan "Sains Islam" dimana sains dikonstruksi berdasarkan wahyu Allah. ${ }^{13}$

Dari latar belakang yang seperti itulah maka sangat menarik untuk diteliti lebih jauh keberadaan SMA Trensains. Seperti apakah sebenarnya epistemologi yang membangunnya, apakah masih terperangkap dalam nalar epistemologi seperti yang telah dibangun oleh islamisasi sains, dan saintifikasi Islam, ataukah memiliki landasan epistemologi yang lebih transformatif dan akan mampu membawa kemajuan Islam.

Dalam penelitian ini, penulis menggunakan jenis penelitian lapangan (field research $)^{14}$ dengan model studi kasus ${ }^{15}$ yang menggunakan metode des-

\footnotetext{
12SMA TRENSAINS Tebuireng Jombang, “TRENSAINS: Jalan Sunyi Pecinta Sains dan al-Qur'an”, dokumen lembaga, h. 16.

${ }^{13}$ Lihat Sains Islam dalam Agus Purwanto, Ayat-ayat Semesta: Sisi al-Qur'an yang Terlupakan (Bandung: Mizan Pustaka, 2013), h. 188.

${ }^{14}$ Dengan penelitian lapangan maka peneliti terjun ke lapangan langsung, mempelajari suatu proses atau penemuan yang terjadi secara alami, mencatat, menganalisis, menafsirkan dan melaporkan serta menarik kesimpulan dari proses-proses tersebut. Lihat Nana Sudjana dan Ibrahim, Penelitian dan Penilaian Pendidikan, (Bandung: Sinar Baru, 1989), h. 199; dan berusaha meneliti atau melakukan studi terhadap realitas kehidupan sosial masyarakat secara langsung. Lihat Masykuri Bakri (ed.), Metodologi Penelitian Kualitatif: Tinjauan Teoritis dan Praktis, (Malang: Lembaga Penelitian UM bekerja sama dengan Visipress, 2002), h. 58.

15Lihat: Robert C. Bogdan dan Sari Knopp Biklen, Qualitative Research for Education: An Introduction to Theory and Methods, (Boston: Aliyn and Bacon, Inc., 1998), h. 105; Robert E. Stake, "Case
} 
kriptif16 melalui pendekatan kualitatif ${ }^{17}$ dan filosofis. ${ }^{18}$ Sedangkan sumber data dalam penelitian ini, yaitu data utama dan data pendukung. Sumber data utama dalam penelitian kualitatif ialah kata-kata dan tindakan, selebihnya ialah data pendukung seperti dokumen dan lain-lain.19 Lokasi penelitian adalah Pesantren Sains (SMA Trensains) Pesantren Tebuireng Jombang, yang beralamatkan di Jl. Jombang-Pare KM. 19 Jombok Ngoro Jombang Jawa Timur. Dalam penelitian ini, penulis akan memahami, menghayati dan menafsirkan berbagai macam hal yang terkait dengan epistemologi sains Islam di SMA Trensains Tebuireng Jombang.

\section{B. Profil Pesantren Sains Tebuireng Jombang}

Pesantren Sains (Trensains) Tebuireng Jombang digagas sejak tahun 2013 oleh Agus Purwanto, D.Sc dosen Fisika Teori ITS Surabaya bersama KH. Salahudin Wahid dengan tujuan utamanya yaitu melahirkan generasi yang tidak sekedar mumpuni dalam bidang sains, tetapi juga kompeten dalam bidang agama, serta menjadikan al-Qur'an sebagai basis pengembangan sains. Konsep Trensains baru teraplikasikan pada tahun 2014 dengan nama SMA Trensains Tebuireng seiring dibangunnya Pesantren Tebuireng 2. Sekolah tersebut terletak di Jl. Jombang-Pare KM. 19 Jombok Ngoro Jombang yang pada saat itu hanya membuka 4 (empat) kelas sebagai wujud dari aplikasi gagasan Trensains.

Trensains (Pesantren Sains) adalah konsep sekolah yang tidak menggabungkan materi Pesantren dengan ilmu umum sebagaimana pesantren modern. Trensains mengambil kekhususan pada pemahaman al-Qur'an, Hadits dan Sains kealaman (natural science) dan interaksinya. Poin terakhir, interaksi

Studies", dalam Norman K. Denzin \& Yvonna S. Lincoln (eds.), Handbook of Qualitative Research, (London: Sage Publications, 1994), h. 236.

${ }_{16}^{16}$ Penelitian deskriptif berusaha mendeskripsikan suatu gejala, peristiwa, kejadian yang sedang terjadi. Lihat Nana Sudjana dan Ibrahim, Penelitian dan Penilaian Pendidikan, (Bandung: Sinar Baru Algesindo, 1989), h. 64.

${ }^{17}$ Pendekatan kualitatif merupakan prosedur penelitian yang menghasilkan data deskriptif; ucapan atau tulisan dan perilaku yang dapat diamati dari orang-orang (subyek) itu sendiri. Lihat Arief Furchan, Pengantar Metode Penelitian Kualitatif, (Surabaya: Usaha Nasional, 1992), hlm. 21-22; Imron Arifin. (Ed), Penelitian Kualitatif dalam Bidang Ilmu-ilmu Sosial dan Keagamaan, (Malang: Kalimasada Press, 1994), h. 45.

${ }^{18}$ Artinya filsafat sebagai suatu proses, yang dalam hal ini filsafat diartikan sebagai suatu aktivitas berfilsafat,dan dalam proses pemecahan suatu masalah tersebut dengan menggunakan suatu cara dari metode tertentu yang sesuai denganobjek permasalahan. Lihat Kaelan, Metode Penelitian Kualitatif Bidang Filsafat, (Yogyakarta: Paradigma, 2005), h. 10.

${ }^{19}$ Lexy J. Moleong, Metodologi Penelitian Kualitatif, (Jakarta: Remaja Rosdakarya, 1999), h. 112. 
antara agama dan sains merupakan materi khas Trensains yang tidak ada pada pesantren modern. Bagi santri Trensains, kemampuan bahasa Arab dan Inggris menjadi prasyarat dasar, selain para santri juga dituntut mempunyai kemampuan nalar matematik dan filsafat yang memadai. Proyeksi kedepan bagi para alumni Trensains adalah ilmuwan sains kealaman, teknolog, dan dokter yang mempunyai basis al-Qur'an yang kokoh.

Dalam melaksanakan visi dan misinya, SMA Trensains menerapkan konsep adapt-adop kurikulum yaitu kurikulum 2013, Kurikulum Cambridge, dan Kurikulum Kearifan Pesantren Sains. Selanjutnya kurikulum tersebut disebut kurikulum semesta. Kurikulum semesta menghendaki setiap santri menempatkan al-Qur'an sebagai kajian utama dalam pengembangan sains. Selain itu, santri terus dipacu agar memilki ketrampilan berpikir ilmiah yang baik, mereka akan dilatih melalui program-program unggulan (My Qur'an, E-UP, B-UP, A-UP, ECamp, A-Camp, Fismat Camp, Tahajud Fisika, Observasi AAS dll.) dengan tujuan agar memiliki kompetensi di bidang al-Qur'an, IPA dan bahasa asing.

Dalam struktur kurikulum SMA Trensains terdiri dari 3 kelompok mata pelajaran yaitu kelompok mata pelajaran wajib (11 SKS), kelompok mata pelajaran peminatan (110 SKS), dan kelompok mata pelajaran kearifan pesantren sains (14 SKS). Kelompok mata pelajaran wajib terdiri atas mata pelajaran bahasa Inggris, bahasa Indonesia, PKN, sejarah, PJOK, dan prakarya. Sedangkan kelompok mata pelajaran peminatan terdiri dari mata pelajaran Sains yaitu kimia, fisika, biologi, dan matematika. Adapun kelompok mata pelajaran kearifan pesantren terdiri dari mata pelajaran filsafat, bahasa Arab, aswaja, ushul fiqh, ulumul Hadits, ulumul Qur'an, dan pelajaran al-Qur'an dan sains.

Pembelajaran berbasis pendekatan metakognitif dan saintifik merupakan basis pengembangan pembelajaran di SMA Trensains Tebuireng. Pendekatan saintifik merupakan suatu proses pembelajaran yang dirancang agar santri dengan aktif mampu mengonstruksi konsep, hukum atau prinsip dengan melalui beberapa tahapan dalam mengamati, merumuskan setiap masalah, mengajukan atau merumuskan hipotesis, mengumpulkan data, menganalisis data, menarik kesimpulan dan mengomunikasikan konsep, hukum atau prinsip yang ditemukan. Pengembangan pendekatan saintifik di SMA Trensains dimaksudkan untuk memberikan pemahaman kepada para santri dalam mengenal, memahami berbagai macam materi dengan menggunakan pendekatan ilmiah. Sehingga santri tidak tergantung pada informasi searah yang di sampaikan oleh guru. 
Sedangkan strategi metakognitif dalam pembelajaran yang dikembangkan di SMA Trensains meliputi tiga tahap, yaitu: merancang apa yang hendak dipelajari; memantau perkembangan diri dalam belajar; dan menilai apa yang dipelajari. Strategi metakognitif ini digunakan pada semua bidang studi. Hal ini bertujuan untuk mengarahkan santri agar bisa secara sadar mengontrol proses berpikir dalam pembelajaran. Untuk merancang pembelajaran yang berkaitan dengan kemampuan metakognitif, sekolah menerapkan strategi ini secara infuse (tambahan) dalam pembelajaran dan bukan merupakan pembelajaran yang terpisah. Di samping itu sekolah juga mengembangkan pembelajaran berbasis jejaring tema yang sama dalam mengembangkan pembelajaran metakognitif. ${ }^{20}$

\section{Epistemologi Sains Islam di SMA Trensains Pesantren Tebuireng Jombang}

Dalam pembahasannya epistemologi tidak dapat meninggalkan persoalan yang terkait dengan sumber ilmu pengetahuan dan beberapa teori tentang kebenaran. Persoalan epistemologi selalu terkait dengan masalah asal mula ilmu pengetahuan diperoleh, apakah melalui akal pikiran semata sebagaimana banyak ditemukan bahasan mengenai aliran rasionalisme, atau diperoleh lewat pengamatan semata seperti dalam aliran empirisme, atau juga dimungkinkan lewat cara lain yaitu melalui intuisi seperti dalam aliran intuisionisme. ${ }^{21}$ Epistemologi sendiri memiliki pengertian sebagai teori pengetahuan, yang membahas tentang bagaimana cara mendapatkan pengetahuan dari objek yang ingin dipikirkan.22 Epistemologi juga merupakan filsafat yang menyelidiki tentang sumber, syarat, serta proses terjadinya pengetahuan (episteme = pengetahuan $/$ knowledge; dan logos = ilmu/ teori/pemikiran), ${ }^{23}$ berarti juga "the branch of philosophy which investigates the origin, sturture, methodes, and validity of knowledge".24 Selain itu, epistemologi juga merupakan cabang filsafat yang berkenaan dengan pencarian hakikat dan kebenaran pengetahuan. ${ }^{25}$

\footnotetext{
${ }^{20}$ Abdul Ghofur, "Profil SMA Trensains Tebuireng Jombang”, http://www.smatrensains.sch.id/ 2015/08/profil-sma-trensains-tebuireng.html, diakses pada tanggal 15 Agustus 2015.

${ }^{21}$ M. Amin Abdullah, "Problem Epistemologis - Metodologis Pendidikan Islam", dalam Abdul Munir Mulkhan, Religiusitas Iptek, (Yogyakarta: Pustaka Pelajar, 1998), h. 49.

${ }^{22}$ Mujamil Qomar, Epistemologi Pendidikan Islam dari Metode Rasional Hingga Metode Kritik, (Jakarta: Erlangga, 2005), h. 1.

${ }^{23} \mathrm{Abd}$. Rachman Assegaf, "Aliran-Aliran dalam Pendidikan Islam”, Materi Program Pascasarjana Doktor (S3) Kependidikan Islam, UIN Sunan Kalijaga Yogyakarta, 2014, h. 44.

24Degobert D. Runes, Dictionary of Philosophy, (New Littlefield, Adams \& Co, 1971), h. 219.

25Miska M. Amin, Epistemologi Islam, (Jakarta: UI Press, 1983), h. 3.
} 
Terkait dengan wacana ilmu pengetahuan, telah banyak diperbincangkan bahwa apa yang terjadi selama ini adalah dikotomi yang cukup tajam antara keilmuan "sekuler" dan keilmuan "agama". Hal ini tidak hanya dirasakan oleh dunia Islam tetapi juga dunia Barat. Ilmu dan agama seolah mempunyai wilayah sendiri-sendiri dan terpisah satu sama lain, baik dari objek formal material, metode penelitian, kriteria kebenaran, peran yang dimaninkan oleh ilmuwan, maupun status teori masing-masing, bahkan sampai pada institusi penyelenggarannya. ${ }^{26}$

Keadaan inilah yang menuntut para ilmuwan untuk melakukan peninjauan ulang atas hubungan agama dan ilmu pengetahuan. Dalam kutipan Wahyu Nugroho, Gregory R. Peterson mencatat beberapa lembaga, penerbitan, seminar dan konferensi yang diidentifikasi sebagai upaya membangun model hubungan antara agama dan sains di dunia barat antara lain, seperti tulisan Ian G. Barbour lewat karyanya, Religion in an Age of Science (1990), Nacey Murphy, Theology in the Age of Scientific Reasoning (1990), Philip Hefner, The Human Factor (1993), Arthur Peacock, Theology for a Scientific Age (1993), dan lainnya.27 Sedangkan dalam dunia Islam, misalnya; Alparslan Acikgenc, dengan "Islamic Worldview"nya, ${ }^{28}$ Seyyed Hossein Nasr, dengan pendekatan "Islamisasi Sains Berbasis Tawhïd"-nya, ${ }^{29}$ Syed Muhammad Naquib al-Attas, dengan "Islamisasi Ilmu Pengetahuan (Islamization of Knowledge) berbasis Tasawuf",30 Ismail Raji al-Faruqi, dengan "Islamisasi Ilmu Pengetahuan (Islamization of Knowledge) Berbasis Fiqih",31 Ziauddin Sardar, dengan "Sains Islam"-nya. 32 Dalam konteks Indonesia, menurut Azhar, ${ }^{33}$ misalnya, jenis studi yang juga berupaya membangun

\footnotetext{
26M. Amin Abdullah, Islamic Studies di Perguruan Tinggi..., h. 92-94.

${ }^{27}$ Wahyu Nugroho, "Teologi Kristen dalam Konteks Sains: Kajian Kritis atas Gagasan Arthur Peacocke", Journal of Religion Issues, Vol. 1, No. 1, 2003, h. 23-43.

${ }^{28}$ Alparslan Acikgenc, "Holisitic Approach to Scientific Traditions, Islam \& Science", Journal of Islamic Perspective on Science, Vol. 1, No. 1, Juni 2003, h. 102.

${ }^{29}$ Seyyed Hossein Nasr, Science and Civilization in Islam, (New York: New American Library, 1970); Seyyed Hossein Nasr,Sains dan Peradaban di dalam Islam, terj.J. Mahyudin, (Bandung: PUSTAKA, 1997).

${ }^{30}$ Syed M. Naquib al-Attas, Islam and Scularism, (Kuala Lumpur: Angkatan Muda Belia Islam Malaysia, 1978); Syed M. Naquib al-Attas, The Concept of Education in Islam, (Kuala Lumpur: Angkatan Muda Belia Islam Malaysia, 1980).

${ }^{31}$ Isma'il Razi al-Faruqi, al-Tauhid: It's Implications for Thought and Life, (Virginia-USA: The International Institute of Islamic Thought, 1992).

32 Ziauddin Sardar,Islamic Futures: The Shapes of Ideas to Come, (New York:Mansell, 1985); Ziauddin Sardar,Explorations in Islamic sciences, (London-New York: Mansell, 1989).

33 Muhammad Azhar, "Metode Islamic Studies: Studi Komparatif antara Islamization of knowledge dan scintification of Islam", Jurnal Mukaddimah, Vol. XV, No. 26. Januari-Juni 2009, h. 67.
} 
hubungan sains dan agama yang ideal telah dirumuskan oleh beberapa pakar Islamic Studies di Indonesia, misalnya: Mukti Ali dengan "Scientific cum Doctriner" (ScD), ${ }^{34}$ Nurcholish Madjid dengan "Islam Peradaban",35 Kuntowijoyo dengan "Islam Sebagai Ilmu",36 dan M. Amin Abdullah dengan metafora "Spider Web"nya, ${ }^{37}$ dan lain sebagainya.

Ikhtiar perumusan hubungan agama dan sains di dalam Islam yang telah ditawarkan oleh para intelektual Muslim setidaknya dapat diklasifikasikan dalam 3 macam model, ${ }^{38}$ yaitu:

1. Islamisasi sains. Pendekatan islamisasi sains ini sebagaimana model yang ditawarkan oleh salah seorang ahli medis Perancis, Maurice. Bucaille, yang pernah menggegerkan dunia Islam ketika menulis suatu buku yang berjudul "La Bible, le Coran et la Science". Model ini bertujuan mencari kesesuaian penemuan ilmiah dengan ayat al-Qur'an. Model ini banyak mendapat kritik, lantaran penemuan ilmiah tidak dapat dijamin tidak akan mengalami perubahan di masa depan. Menganggap al-Qur'an sesuai dengan sesuatu yang masih bisa berubah berarti menganggap al-Qur'an juga bisa berubah. Islamisasi Sains berusaha menjadikan penemuan-penemuan sains besar abad ke-20 yang mayoritas terjadi di Barat, dapat dimanfaatkan untuk meningkatkan keimanan umat Islam. Misalnya, penemuan ultrasonografi yang dapat melihat proses terbentuknya janin di dalam perut, atau penemuan kecepatan cahaya, diklaim sebagai telah disebutkan di dalam al-Qur'an, sehingga diharapkan makin mempertebal iman seorang Muslim bahwa al-Qur'an telah mendahului sains, karena diturunkan oleh Allah yang Maha Mengetahui. Inilah hubungan yang dikembangkan banyak Muslim saat ini, dan yang menonjol adalah Harun Yahya. ${ }^{39}$ Hubungan ini mendapat banyak kritik, bahwa hubungan ini hanya sekedar menghubung-hubungkan hal-hal yang semula tidak berhubungan (othakathik-gathuk). Hubungan ini juga bisa berdampak negatif, ketika fakta sains

\footnotetext{
${ }^{34}$ Mukti Ali, "Metodologi Ilmu Agama Islam", dalam Taufik Abdullah dan M. Rusli Karim, Metodologi Penelitian Agama: Sebuah Pengantar, (Yogyakarta: Tiara Wacana, 2006).

${ }^{35}$ Nurcholish Madjid, Islam Doktrin dan Peradaban, (Jakarta: Paramadina, 1992). 2006).

${ }^{36}$ Kuntowijoyo, Islam Sebagai Ilmu: Epistemologi, Metodologi dan Etika, (Yogyakarta: Tiara Wacana,

${ }^{37}$ Amin Abdullah, Islamic Studies di Perguruan Tinggi..., h. 107.

${ }^{38}$ Lihat penjelasan lebih lanjut, Amin Abdullah, Islamic Studies di Perguruan Tinggi ..., h. 131-162.

${ }^{39}$ Lihat Maurice Bucaille, Bibel Qur'an dan Sains, terj. A. Rasyidi, (Jakarta: Bulan Bintang, 1992).
} 
yang dimaksud ternyata di masa depan harus dikoreksi secara signifikan, karena ada data atau model analisis yang baru. Model ini di kalangan ilmuwan Muslim Malaysia biasa disebut dengan "Model Remeh", Hal ini karena sama sekali tidak mengindahkan sifat kenisbian dan kefanaan penemuan dan teori sains Barat dibanding dengan sifat mutlak dan abadi al-Qur'an. Penemuan dan teori sains Barat berubah-ubah mengikut perubahan paradigma, contohnya dari paradigma klasik Newton yang kemudian berubah menjadi paradigma quantum Planck dan kenisbian Einstein. ${ }^{40}$

2. Saintifikasi Islam. Pendekatan ini merupakan upaya mencari dasar sains pada suatu pernyataan yang dianggap benar dalam Islam. Contohnya penelitian-penelitian di bawah ini masuk kategori saintifikasi Islam: a) Penelitian dampak jangka panjang pada konsumsi makanan haram (babi, bangkai, darah). b) Penelitian dengan alat-alat pencatat denyut jantung (EKG) atau sinyal otak (EEG), juga mengambil sampel darah dan menganalisisnya, pada orang-orang yang rajin melakukan shalat (khususnya tahajud) dan puasa. Salah satu contoh konkret adalah penelitian yang dilakukan oleh Prof. Dr. Muhammad Sholeh dan Prof. Dr. Suhartono Taat Putra, dengan penelitiannya yang berjudul "Pengaruh Shalat Tahajud terhadap Perubahan Peningkatan Respon Ketahanan Tubuh Imunologik (Suatu Pendekatan Psikoneuroimunologi)". Penelitian-penelitian saintifik tentang hal-hal di atas selalu menarik (amazing) bagi kaum Muslimin, sehingga bahkan kadang-kadang lupa menguji kebenaran sainfitiknya ketika kesimpulannya sudah seolah-olah mendukung dalil. Sebaliknya ketika hasil penelitian berlawanan dengan yang dikehendaki, misalnya bahwa "tidak ada perbedaan yang signifikan antara orang yang terbiasa mengkonsumsi babi dengan yang tidak", maka tulisan ini cenderung dijauhi, ini contoh suatu bentuk "kepengecutan ilmiah". ${ }^{41}$

3. Sains Islam. Model ketiga yaitu sains Islam inilah yang dianggap paling efektif daripada model sebelumnya. Sains Islam adalah sains yang sepenuhnya dibangun atas pondasi al-Qur'an dan al-Sunnah. Sains Islam dapat terwujud

\footnotetext{
${ }^{40}$ Lihat Wan Ramli bin Wan Daud, dan Shaharir bin Mohamad Zain, "Pemelayuan, Pemalaysiaan dan Pengislaman Ilmu Sains dan Teknologi dalam Konteks Dasar Sains Negara", Jurnal Kesturi, No. 1. 1999.

${ }^{41}$ Lihat Fahmi Ahmar, "Belajar Sains Islam, Bukan Saintifikasi Islam”, dalam www.globalmuslim. web.id, diakses pada 10 Agustus 2015.
} 
apabila terjadi adanya kesadaran normatif (normative consciousness) dan kesadaran historis (historical conciousness). Kesadaran normatif muncul karena secara eksplisit atau implisit al-Qur'an dan al-Sunnah menekankan pentingnya ilmu pengetahuan. Kesadaran normatif tersebut kemudian menumbuhkan kesadaran historis yang menjadikan perintah al-Qur'an dan alSunnah sebagai inspirasi dalam membaca realitas kehidupan. Maka tumbuhlah kesadaran bahwa petunjuk al-Qur'an tentang sains tidak akan membumi tanpa usaha sadar dari para saintis untuk membeca realitas, baik kemajuan sains yang pernah diraih oleh bangsa lain, maupun melakukan kontekstualisasi ajaran dalam kegiatan penelitian sains. ${ }^{42}$

Dalam kaitannya dengan sains Islam, maka berdirinya pesantren sains yang dalam hal ini terwujud dalam bentuk SMA Trensains Pesantren Tebuireng Jombang juga mengambil bentuk pola hubungan antara agama dan sains dalam bentuk sains Islam. Di mana nantinya diharapkan akan mampu melahirkan generasi muda yang mampu menggali dan dan melakukan konstruksi sains dari al-Qur'an dan al-Hadits. ${ }^{43}$ Oleh karena itu bangunan sains Islam yang dikembangkan di pesantren sains ini harus dibangun dari tiga pilar: ontologi, aksiologi dan epistemologi yang bersumber dari prinsip tawhìd dan mengkristal dalam Rukun Iman dan Rukun Islam. Ontologi Islam jelas tidak akan menolak hal yang gaib. Realitas bukan hanya objek yang dapat dilihat, diraba, dirasakan, tetapi juga yang tidak dapat dilihat. Objek pengetahuan ada dua, yaitu yang tampak oleh mata dan yang tidak tampak, serta terdapat realitas dibalik realitas material. ${ }^{44}$

Sedangkan aksiologi Islam adalah dikenalnya Sang Pencipta melalui polapola ciptaan-Nya dan diketahuinya watak sejati segala sesuatu, sebagaimana yang diberikan oleh Tuhan. Watak sejati akan memperlihatkan kesatuan hukum alam, Sunnatullāh, keterkaitan seluruh bagian dan aspeknya sebagai refleksi dari kesatuan prinsip Ilahi. Bagi seorang ilmuwan, keberhasilan upaya menguak pola ciptaan dan kesatuan hukum alam akan membuatnya makin

\footnotetext{
${ }^{42}$ Muqowim, "Genealogi Intelektual Saintis Muslim: Sebuah Kajian Tentang Pola Pengembangan Sains dalam Islam pada Periode Abbasiyyah", Disertasi, Program Pascasarjana UIN Sunan Kalijaga Yogyakarta, 2011, h. 486-487.

43Wawancara dengan Waka Kurikulum BapakAbdul Ghofur, pada tanggal 10 Agustus 2015.

${ }^{44}$ Lihat QS. al-Haqqah [69]: 38-39, artinya; "Maka aku bersumpah dengan apa yang kamu lihat dan dengan apa yang tidak kamu lihat". Departemen Agama RI, al-Qur'an dan Terjemahnya (Surabaya: Mekar, 2002).
} 
tunduk kepada sang Khaliq, dan tidak membuat mereka takabur, arogan dan mengabaikan Sang Pencipta, sebagaimana diisyaratkan dalam QS. Ali Imran [3]; 191.45

Sedangkan pilar ketiga, adalah pilar epistemologi yaitu bagaimana dan dengan apa ilmu pengetahuan diperoleh. Al-Qur'an menyebutkan ada tiga piranti manusia untuk memperoleh pengetahuan, yaitu pendengaran, penglihatan dan fu'âd, sebagaimana yang telah disebutkan dalam QS. al-Nahl [16]: 78. ${ }^{46}$ Berangkat dari kondisi tidak tahu, maka setelah lahir manusia belajar sedikit demi sedikit dengan ketiga piranti tersebut. Tetapi pada ayat tersebut tidak diakhiri dengan redaksi la'allakum ta'lamūn (agar engkau mengetahui), akan tetapi menggunakan la'allakum tashkurūn (agar engkau bersyukur), artinya mengaktifkan ketiga piranti (telinga, mata dan hati) tidak sekedar pada taraf mengetahui sesuatu, tetapi manusia harus bersyukur atas karunia pengetahuan yang dimiliki dan diperoleh melalui ketiga piranti tersebut. ${ }^{47} \mathrm{Di}$ sinilah letak epistemologi dalam sains Islam yaitu wahyu dan petunjuk Tuhan, agar dapat mengetahui hakikat dirinya.

Dalam epistemologi sains Islam, al-Qur'an juga dapat dikonfirmasi kebenarannya oleh fenomena alam dan diri manusia, hal ini dapat berarti bahwa al-Qur'an dapat menjadi sumber informasi bagi suatu fenomena alam, atau alQur'an dapat menjadi basis bagi bangunan teori tentang alam. Sains Islam dalam perspektif ini dapat dimaknai sebagai sains yang premis dasarnya diambil langsung dari wahyu atau ayat-ayat al-Qur'an. Di dalam al-Qur'an terdapat 800 ayat, ${ }^{48}$ yang menyodorkan informasi tentang alam yang sampai saat ini belum pernah disentuh secara berarti. Ayat-ayat ini tidak memberikan pesan moral, akan tetapi informasi awal bagi pemahaman yang lebih utuh

45Lihat QS. Ali Imran [3]: 191, artinya: “(yaitu) orang-orang yang mengingat Allah sambil berdiri atau duduk atau dalam keadan berbaring dan mereka memikirkan tentang penciptaan langit dan bumi (seraya berkata): "Ya Tuhan Kami, Tiadalah Engkau menciptakan ini dengan sia-sia, Maha suci Engkau, Maka peliharalah Kami dari siksa neraka". Departemen Agama RI, al-Qur'an dan Terjemahnya, (Surabaya: Mekar, 2002).

46Lihat QS. al-Nahl [16]: 78, artinya: "Dan Allah mengeluarkan kamu dari perut ibumu dalam keadaan tidak mengetahui sesuatu pun, dan Dia memberi kamu pendengaran, penglihatan dan hati, agar kamu bersyukur". Departemen Agama RI, al-Qur'an dan Terjemahnya, (Surabaya: Mekar, 2002).

${ }^{47}$ Agus Purwanto, Ayat-ayat Semesta: Sisi al-Qur'an yang Terlupakan, (Bandung: Mizan Pustaka, 2013), h. 154-161. 187.

${ }^{48}$ Lihat 800 ayat-ayat kawniyyah di dalam al-Qur'an, Agus Purwanto, Ayat-ayat Semesta..., h. 35- 
tentang alam semesta dan bagian-bagiannya. ${ }^{49}$ Sebagai contoh, sebagaimana yang disebutkan dalam QS. al-Baqarah [2]: 74, ${ }^{50}$ bahwa dengan ayat tersebut seorang ilmuwan (tepatnya geolog Muslim) dapat berangkat dari informasi ini untuk meneliti air, batu, dan sungai. Bukan batu-batu yang ada di sungai, melainkan bagaimana batu dapat memancarkan air. Upaya yang terjadi selama ini, tepatnya sejak zaman Renaisans, adalah penelitian akan alam dilakukan secara murni, baru kemudian ilmuwan (agamawan) mencarikan pembenaran dalam kitab suci, termasuk al-Qur'an. Upaya seperti ini dikenal sebagai upaya islamisasi sains. Upaya ideal yang sekaligus membedakan ilmuwan Muslim dengan ilmuwan yang lainnya adalah menjadikan al-Qur'an sebagai basis dan pijakan dalam mengkonstruk teori ilmiah. ${ }^{51}$

Untuk melakukan konstruksi pengetahuan, dalam Islam juga dapat dilakukan dengan pendekatan paradigma al-Qur'an sebagaimana yang telah ditawarkan Kuntowijoyo. Dengan paradigma al-Qur'an berarti dalam melakukan konstruksi pengetahuan, juga memungkinkan bagi umat Islam untuk merumuskan desain-desain besar mengenai sistem Islam, termasuk dalam hal ini sistem ilmu pengetahuan. Jadi di sini paradigma al-Qur'an juga akan berfungsi untuk memberikan wawasan epistemologis. ${ }^{52}$ Secara epistemologis dengan paradigma al-Qur'an tersebut maka ilmu pengetahuan dapat di konstruksi darinya dan teori-teori ilmu pengetahuan baru juga dapat dimunculkannya. Disinilah sains Islam akan menemukan tempatnya.

Dalam sains Islam hendaknya pola yang dibangun tidak hanya memiliki pola "interaksi satu arah". Oleh karena itu hendaknya selain sains Islam secara epistemologis mampu mengkonstruk sains dan teknologi dari paradigma yang dibangun oleh al-Qur'an, maka juga harus mampu melakukan interaksi yang lebih dinamis dengan sains Barat yang telah berkembang sebelumnya. Kesalahan yang ada selama ini, bahwa aliran-aliran epistemologi pengetahuan, baik rasionalisme, empirisme maupun intusionisme, masing masing berdiri

\footnotetext{
${ }^{49}$ Agus Purwanto, Ayat-ayat Semesta..., h. 164.

${ }^{50}$ QS. al-Baqarah [2]: 74,artinya: “Kemudian setelah itu hatimu menjadi keras seperti batu, bahkan lebih keras lagi. Padahal diantara batu-batu itu sungguh ada yang mengalir sungai-sungai dari padanya dan diantaranya sungguh ada yang terbelah lalu keluarlah mata air dari padanya dan diantaranya sungguh ada yang meluncur jatuh, karena takut kepada Allah dan Allah sekali-sekali tidak lengah dari apayang kamu kerjakan". Departemen Agama RI, al-Qur'an dan Terjemahnya (Surabaya: Mekar, 2002).

${ }^{51}$ Agus Purwanto, Ayat-ayat Semesta ..., h. 166.

${ }^{52}$ Kuntowijoyo, Islam sebagai Ilmu ..., h. 11.
} 
sendiri, dan mengambil jarak diantara mereka. Oleh karena itu saat ini perlu dilakukan usaha "reorientasi epistemologis" dengan merubah cara pandang terhadap aliran-aliran epistemologi, untuk dapat menempatkan seluruh aliran tersebut sebagai estafeta-epistemologis yang saling terkait (coherence) antara yang satu dengan yang lain, bukan suatu hal yang selalu bertentangan (kontradiktif). Al-Qur'an sendiri yang merupakan sumber utama ajaran Islam, di dalamnya tidak terdapat satu ayat pun yang mempertentangkan sumber dan cara memperoleh pengetahuan. Karena itu apakah pengetahuan diperoleh melalui pengematan pancaindra (empirisme), atau daya nalar (rasionalisme) maupun pengetahuan yang diperoleh atas anugerah dari Allah yang berupa hikmah (intusionisme), secara keseluruhan dapat diketemukan sumbernya dalam al-Qur'an. ${ }^{53}$

Di sinilah epistemologi pengetahuan dalam Islam akan menemukan tempatnya, dimana epistemologi pengetahuan dalam Islam memiliki bangunan yang kokoh, karena epistemologi yang lebih bersifat komprehensif, koheren dan integratif. Proses ini dibenarkan, karena epistemologi pada dasarnya adalah upaya untuk menimbang dan menentukan nilai kognitif pengalaman manusia dalam interaksinya yang global, baik dengan dirinya, lingkungan sosial, agama, budaya dan alam sekitarnya. Interaksi berbagai ranah inilah yang membuat metodologi pendekatan epistemologi juga harus bersifat holistik dan integratif. Metodologi pendekatan epistemologi yang integratif tersebut tidaklah harus menghilangkan sifat epistemologi yang berupa evaluatif, normatif dan kritis. Evaluatif berarti bersifat menilai, ia menilai apakah suatu keyakinan, sikap, pernyataan, pendapat, teori pengetahuan dapat dibenarkan, dijamin kebenarannya, atau memiliki dasar yang dapat dipertanggungjawabkan. Normatif berarti menentukan norma atau tolak ukur, dalam hal ini tolak ukur kenalaran bagi kebenaran pengetahuan. Sedangkan kritis berarti banyak mempertanyakan dan menguji kenalaran cara maupun hasil kegiatan manusia mengetahui. Dalam hal ini yang dipertanyakan adalah baik asumsiasumsi, cara kerja atau pendekatan yang diambil, maupun kesimpulan yang ditarik dalam berbagai kegiatan kognitif manusia. ${ }^{54}$

53Muhammad Azhar, dkk., Studi Islam dalam Percakapan Epistemologis, (Yogyakarta: Sipres, 1998), h. 129-130. h. 18-19.

54J. Sudarminta, Epistemologi Dasar: Pengentar Filsafat Pengetahuan, (Yogyakarta: Kanisius, 2002), 
Paradigma epistemologis yang seperti itu memberi pengertian bahwa ilmu pengetahuan dalam Islam juga harus mau bertegur sapa dengan ilmu pengetahuan Barat. Karena memang harus diakui bahwa ilmu pengetahuan Barat telah berkembang sedemikian pesat, oleh karena itu meninggalkan ilmu pengetahuan yang telah ada bukanlah merupakan tindakan bijak dan meninggalkan ilmu pengetahuan yang telah berkembang pesat tersebut akan menyebabkan ketertinggalan dan ketidakmampuan untuk maju secara cepat, semakin tertinggal jauh dari kemajuan yang telah ada dan berakhir menjadi orang (bangsa) yang lemah dan bergantung pada kekuatan asing. Namun, totalitas dalam ilmu pengetahuan tanpa sikap kritis juga bukan merupakan tindakan yang tepat dan menutup fakta atas aneka krisis zaman modern. Oleh karena itu peradaban alternatif perlu dikembangkan tanpa harus tertinggal dalam perkembangan ilmu pengetahuan yang telah ada saat ini..$^{55}$

Ilmu pengetahuan, lebih khususnya sains dan teknologi menjadi determinan utama bangsa dan peradaban modern, oleh karena itu penguasaan ilmu termasuk ilmu alam atau sains natural merupakan keniscayaan, tetapi agar tidak mengulang terperosok dalam kubangan nihilisme maka iman dan ilmu harus dibangun serempak. Pendidikan dengan model gabungan antara lembaga sekolah dan pesantren dipercaya merupakan jalan untuk mentransformasi gagasan, pemahaman dan kesadaran ini. Dari sinilah maka berdirinya SMA Trensains yang kependekan dari pesantren sains dan merupakan sintesis dari pesantren dan sekolah umum bidang sains, diproyeksikan untuk mencetak generasi Muslim yang ahli sains dan teknologi. 56

Trensains merupakan sintesis dari pesantren dan sekolah umum bidang sains. Trensains merupakan lembaga pendidikan pesantren setingkat SMA yang merupakan proyek baru di Indonesia, bahkan mungkin di dunia Islam Sunni, karena kegiatan utamanya adalah mengkaji dan meneliti ayat-ayat semesta yang terkandung dalam al-Qur'an al-Karim dan Hadits Nabawi. Trensains tidak menggabungkan materi pesantren dan ilmu umum sebagaimana pesantren modern dan kombinasi. Trensains mengambil kekhususan pada pemahaman al-Qur'an dan al-Hadits, sains kealaman (natural science) dan interaksinya. Poin terakhir yaitu interaksi antara agama dan sains merupakan

\footnotetext{
${ }^{55}$ Agus Purwanto, Ayat-ayat Semesta.., h. 166-167.

56SMA Trensains Tebuireng Jombang, "Trensains: Jalan Sunyi Pecinta Sains dan al-Qur'an”, dokumen lembaga, h. 16.
} 
materi khas Trensains dan tidak ada dalam ponpes modern. Para santri Trensains juga dibimbing untuk mempunyai kemampuan nalar matematik dan filsafat yang memadai. Konsep dasar limit, diferensial dan integral perlu diperkenalkan sebagai alat analisis dan memahami konsep fisika. Nalar dan spirit filosofis diperlukan untuk berpikir runut, tuntas dan mendasar. Sejarah filsafat Yunani awal memperlihatkan spirit pemikiran paling awal tentang alam dan realitas. Sejarah aliran pemikiran perlu diperkenalkan untuk memahami adanya aneka cara pandang atas alam. ${ }^{57}$

Penguasaan ilmu termasuk ilmu alam atau sains natural merupakan keniscayaan, tetapi agar tidak mengulang terperosok dalam kubangan nihilisme maka iman dan ilmu harus dibangun serempak. Sains harus bertumpu pada prinsip-prinsip Islam dan digali dari sumber utama al-Qur'an. Islam sendiri juga harus ditampilkan dalam wajah yang utuh termasuk wajah ilmu pengetahuannya. Terdapat 800 ayat kawniyyah yang terkait dengan alam semesta di dalam al-Qur'an, lima kali lebih banyak dari ayat fikih jelas tidak sepatutnya diabaikan. Inilah yang menjadi prioritas didirikannya Trensains, yaitu mengkonstruksi sains dengan merujuk pada konsep-konsep alam (ayatayat kawniyyah) yang dijumpai dalam al-Qur'an, atau dengan kata lain sains dikonstruksi berdasarkan wahyu Allah.

Sebagaimana telah dijelaskan sebelumnya bahwa hubungan sains dan agama Islam selama ini memiliki berbagai macam model. Trensains tidak melakukan pendekatan dengan hanya melakukan "Islamisasi Sains", yaitu pembeberan ayat-ayat dengan menggunakan sains yang sudah ada, juga tidak melakukan pendekatan dengan cara "Saintifikasi Islam", yaitu hanya berusaha menjelaskan Islam dengan terminologi sains. Akan tetapi Trensains mengajukan pendekatan "Sains Islam" dimana sains dikonstruksi berdasarkan wahyu Allah. ${ }^{58}$ Ini berarti fungsi petunjuk al-Qur'an juga berlaku bagi konstruksi ilmu pengetahuan dengan memberi petunjuk tentang prinsip-prinsip sains, yang selalu dikaitkan dengan pengetahuan metafisik dan spiritual. Artinya dalam epistemologi Islam, wahyu dan sunah juga dapat dijadikan sebagai sumber inspirasi bagi bangunan ilmu pengetahuan. Dalam tataran ini, epistemologi sains Islam adalah epistemologi sains modern plus atau diperluas, yaitu plus

\footnotetext{
57SMA TRENSAINS Tebuireng Jombang, "Trensains: Jalan Sunyi Pecinta Sains dan alQur'an",dokumen lembaga, h. 16-17.

${ }^{58}$ Lihat sains Islam dalam Agus Purwanto, Ayat-ayat Semesta ..., h. 188.
} 
penerimaan wahyu sebagai sumber informasi dan plus metodologi yang tidak tunggal atau kemajemukan metodologi, seperti penerimaan metode takwil. Metode terakhir ini terkait dengan upaya penyingkapan realitas yang lebih tinggi, yang hanya mungkin apabila pikiran tercerahkan oleh cahaya iman dan disentuh oleh keberkatan yang tumbuh dari wahyu. Karena itu dapat dimengerti mengapa penyucian jiwa dipandang sebagai bagian yang terpadu dan integral dari metodologi pengetahuan Islam. .9

Dengan pendekatan yang dipilih oleh Trensains yaitu sains dan teknologi dikonstruksi berdasarkan wahyu Allah. Maka dalam implementasinya, akan memunculkan sistem pendidikan yang unik dan berbeda dengan sistem pendidikan yang selama ini ada. Terutama dalam implementasi kurikulum, contohnya SMA Trensains Tebuireng Jombang, mengimplementasikan kurikulum unifikasi, yaitu menerapkan kurikulum 2013 dengan mengadopsi dan mengadaptasi kurikulum Cambridge serta kurikulum kearifan pesantren sains yang menjadi ciri khas Trensains Tebuireng. Kurikulum tersebut diintegrasikan dengan sistem SKS (Sistem Kredit Semester) sebagai pedoman oprasional pembelajaran. Sistem Kredit Semester (SKS) dirancang untuk mewujudan konsep belajar tuntas, yang memungkinkan peserta didik dapat belajar sesuai dengan kecepatan belajarnya. Struktur mata pelajaran SMA Trensains mencakup MPW (Mata Pelajaran Wajib) A dan B, MPP (Mata Pelajaran Peminatan), dan MPKP (Mata Pelajaran Kearifan Pesantren). Mata Pelajaran Kearifan pesantren merupakan ciri kas dari kurikulum yang ada di SMA Trensains, yang merupakan wujud dari integrasi antara agama dan sains, yang terdiri atas Filsafat Sains I - II, al-Qur'an dan Sains I - IV, dimana di dalamnya akan dibahas tema-tema yang terkait dengan interaksi antara al-Qur'an dan sains. ${ }^{60}$

Dengan kurikulum pendidikan yang ditawarkan oleh pesantren sains yang seperti itulah diharapkan akan mampu mencapai visi yang dicanangkan, yaitu lahirnya generasi yang memegang teguh al-Qur'an dan Sunnah, menyintai dan mengembangkan sains, mempunyai kedalaman filosofis dan keluhuran akhlak. Dengan berdirinya Trensains ini juga diharapkan akan mampu membentuk generasi Muslim yang mampu membangun paradigma (filsafat) ontologis, epistemologis dan aksiologis ilmu berdasarkan al-Qur'an, sehingga secara

\footnotetext{
${ }^{59}$ Agus Purwanto, Ayat-ayat Semesta ..., h. 193-194.

${ }^{60}$ Lihat SMA Trensains Tebuireng "Struktur Kurikulum SMA Trensains Tebuireng", dokumen lembaga.
} 
implisit terlihat adanya hirarki 'ilm (sains) - hikmah (filsafat) - kitāb (Qur'an), seperti yang telah diisyaratkan dalam al-Qur'an ${ }^{61}$ itu sendiri dalam membangun sains Islam.

\section{Upaya Pesantren Sains dalam Membangun Peradaban Islam}

Berdirinya pesantren sains yang dalam hal ini terwujud dalam bentuk lembaga pendidikan formal SMA Trensains Pesantren Tebuireng Jombang sebenarnya dilatarbelakangi oleh problematika umat Islam yang sampai saat ini tidak mampu lagi menjadi pioner di kancah persaingan dunia Internasional, padahal di era abad pertengahan umat Islam pernah menjadi barometer peradaban dunia. Saat ini umat Islam di berbagai belahan dunia ada dalam kondisi yang memprihatinkan, baik karena permasalahan ekonomi, sosial, budaya, keamanan bahkan ketidakmampuannya dalam menguasai kemajuan sains dan teknologi. Kondisi inilah yang antara lain menjadi alasan kenapa dalam dunia Islam harus didirikan sebuah lembaga pendidikan yang terkonsentrasi pada penguasaan sains dan teknologi. Hal ini dikarenakan penguasaan terhadap sains dan teknologi merupakan hal yang mutlak diperlukan di era zaman modern seperti saat ini. Tanpa penguasaan sains dan teknologi dapat dipastikan akan tergerus oleh zaman dan menjadi bangsa yang tertinggal dari peradaban dunia. ${ }^{62}$

Tanda-tanda dari wujudnya peradaban, menurut Ibn Khaldun adalah berkembangnya ilmu pengetahuan seperti fisika, kimia, geometri, aritmetik, astronomi, optic, kedokteran, dan sebagainya. Bahkan maju mundurnya suatu peradaban tergantung atau berkaitan dengan maju mundurnya ilmu pengetahuan. Jadi substansi peradaban yang terpenting dalam teori Ibn Khaldun adalah ilmu pengetahuan. Namun ilmu pengetahuan tidak mungkin hidup tanpa adanya komunitas yang aktif mengembangkannya. Karena itu suatu peradaban harus dimulai dari suatu "komunitas kecil" dan ketika komunitas itu membesar maka akan lahir perdaban yang semakin besar. Komunitas itu

61Lihat QS. al-Nisa' [4]: 113, yang artinya: “Sekiranya bukan karena karunia Allah dan rahmat-Nya kepadamu, tentulah segolongan dari mereka berkeinginan keras untuk menyesatkanmu. Tetapi mereka tidak menyesatkan melainkan dirinya sendiri, dan mereka tidak dapat membahayakanmu sedikitpun kepadamu. dan (juga karena) Allah telah menurunkan kitab dan Hikmah kepadamu, dan telah mengajarkan kepadamu apa yang belum kamu ketahuidan adalah karunia Allah sangat besar atasmu". Departemen Agama RI, al-Qur'an dan Terjemahnya (Surabaya: Mekar, 2002).

62 Wawancara dengan Kepala Sekolah SMA Trensains pesantren sains Tebuireng Jombang Bapak Rofiq, pada tanggal 10 Agustus 2015. 
biasanya muncul di perkotaan atau bahkan membentuk suatu kota. Dari kota itulah akan terbentuk masyarakat yang memiliki berbagai kegiatan kehidupan yang daripadanya timbul suatu sistem kemasyarakat dan akhirnya lahirlah suatu negara. Kota Madinah, kota Cordova, kota Baghdad, kota Samara, kota Cairo dan lain-lain adalah sedikit contoh dari kota yang berasal dari komunitas yang kemudian melahirkan negara. Tanda-tanda lahir dan hidupnya suatu peradaban bagi Ibn Khaldun di antaranya adalah berkembanganya teknologi, (tekstil, pangan, dan papan/arsitektur), kegiatan eknomi, tumbuhnya praktek kedokteran, kesenian (kaligrafi, musik, sastra dsb). Di balik tanda-tanda lahirnya suatu peradaban itu terdapat komunitas yang aktif dan kreatif menghasilkan ilmu pengetahuan.

Lebih jelasnya menurut Ibn Khaldun, wujud suatu peradaban merupakan produk dari akumulasi tiga elemen penting, yaitu: (1) kemampuan manusia untuk berpikir yang menghasilkan sains dan teknologi, (2) kemampuan berorganisasi dalam bentuk kekuatan politik dan militer dan (3) kesanggupan berjuang untuk hidup. ${ }^{63}$ Jadi kemampuan berpikir merupakan elemen asas suatu peradaban. Suatu bangsa akan beradab (berbudaya) hanya jika bangsa itu telah mencapai tingkat kemapuan intelektual tertentu. Sebab kesempurnaan manusia ditentukan oleh ketinggian pemikirannya. Suatu peradaban hanya akan wujud jika manusia di dalamnya memiliki pemikiran yang tinggi sehingga mampu meningkatkan taraf kehidupannya. Suatu pemikiran tidak dapat tumbuh begitu saja tanpa sarana dan prasarana ataupun supra-struktur dan infra-struktur yang tersedia.

Proyek membangun kembali peradaban Islam tidak dapat dilakukan hanya dengan melalui satu dua bidang kehidupan. Ia merupakan proses bersinergi, simultan dan konsisten. Untuk itu maka proyek ini perlu disadari bersama sebagai sesuatu yang wajib (fardu 'ayn) dan merupakan tanggung jawab yang perlu dibebankan kepada seluruh anggota masyarakat Muslim. Secara historis, jika kita menengok sejarah kejayaan Islam di Baghdad maka kita akan temui gerakan pengembangan ilmu pengetahuan yang bersinergi. Gerakan yang dimulai dengan penterjemahan karya-karya asing, khususnya Yunani itu bukan gerakan seporadis atau gerakan pinggiran. Gerakan itu didukung oleh elit

\footnotetext{
63Ibn Khaldun 'Abd al-Rahman ibn Muhammad, The Muqaddimah: an Introduction to History, terj. Franz Rosenthal, 3 jilid, editor N.J. Dawood. (London, Routledge \& Kegan Paul, 1978), h. 54-57.
} 
masyarakat Baghdad: seperti khalifah dan putera mahkotanya, pegawai negara dan pimpinan militer, pengusaha dan bankers, dan sudah tentu ulama dan saintis. Ia bukan proyek kelompok tertentu. Selain itu, gerakan disubsidi oleh dana yang tidak terbatas dari perusahaan negara maupun swasta. Yang terpenting, ia dilakukan dengan menggunakan metodologi ilmiah yang akurat dengan alat filologi yang eksak, sehingga ilmu pengetahuan yang berasal dari asing dapat diterjemahkan dengan tepat oleh umat Islam.

Usaha-usaha yang pernah dilakukan umat Islam yang seperti itu menunjukkan bahwa pengembangan ilmu pengetahuan adalah sentral sifatnya. Oleh karena itu pada zaman sekarang juga perlu terus dilakukan pengembangan ilmu pengetahuan secara bersinergi, simultan dan konsisten. Dari perkembangan ilmu pengetahuan inilah kemudian dikembangkan bidang-bidang lain baik secara simultan ataupun secara gradual. Ilmu pengetahuan sudah barang tentu diperlukan oleh semua kelompok apapun orientasi dan strategi perjuangannya. Pembangunan politik, ekonomi, pendidikan, perbankan Islam dan lain sebagainya tidak bisa tidak harus dimulai dari ilmu pengetahuan. Selanjutnya, karena spesialisasi dalam ilmu pengetahuan baik agama maupun sekuler begitu kental, maka seorang sarjana satu bidang biasanya tidak menguasai bidang yang lain. Lebih memprihatinkan lagi sarjana ilmu keislaman buta ilmu-ilmu umum (sekuler) dan begitu juga sebaliknya sarjana ilmu umum tidak tahu sama sekali ilmu agama, meskipun mereka adalah Muslim. ${ }^{64}$

Dalam situasi seperti inilah maka berdirinya pesantren sains yang dalam hal ini terwujud dalam bentuk pendidikan formal SMA Trensains Pesantren Tebuireng Jombang, diharapkan dalam meminimalisir problematiak tersebut. Diharapkan Trensains akan mampu mencetak kader ulama' yang mumpuni dalam bidang agama sekaligus mampu menguasai perkembangan sains dan teknologi. Hal tersebut karena semakin disadari bahwa penguasaan sains dan teknologi sekaligus pemahaman ilmu agama yang kuat akan mampu mengantarkan umat Islam menuju kejayaan peradabannya kembali. Dalam pembelajaran di SMA Trensains pola interaksi antara agama dan sains merupakan topik kajian utama dari Trensains. Tidak sekedar tempelisasi ayat (mencari

${ }^{64}$ Hamid Fahmy Zarkasyi, "Membangun Peradaban Islam", Makalah, disampaikan dalam Workshop Pemikiran Ideologis, Forum Ukhuwwah Islamiyah, Daerah Istimewa Yogyakarta, 15 April 2007, h. 30-31. 
dasar ayat al-Qur'an yang berhubungan dengan sains) tetapi lebih menekankan konsep dialektika antara al-Qur'an dan sains.

Konsep tersebut adalah penekanan setiap pembelajaran sains yang ada di SMA Trensains. Santri dibekali beberapa disiplin ilmu sebagai tool dalam memahami konten-konten Trensains. Disiplin ilmu tersebut adalah ulumul qur'an, ulumul Hadits, bahasa arab, balaghoh, matik, dan filsafat. Ilmu-ilmu ini adalah ilmu yang wajib dikuasai oleh setiap santri. Setiap santri trensains diproyeksikan untuk menjadi ulama sains kealaman, yakni orang-orang yang dapat mengembangkan sains dengan sumber inspirasi ayat-ayat kawniyyah yang ada di dalam al Qur'an. Semangat ini didasari atas keinginan yang kuat untuk mengembalikan kejayaan dan peradaban umat Islam sebagaimana zaman dahulu. ${ }^{65}$

\section{E. Kesimpulan}

Saat ini Barat menjadi acuan dan pionir dalam pengembangan sains dan teknologi. Padahal secara historis, tampak bahwa kemajuan Barat berawal dari adopsi kemajuan ilmu pengetahuan di dunia Islam pada abad keemasan Islam. Permasalahan yang ada, hingga saat ini masih kuat anggapan dalam masyarakat Muslim bahwa "agama" dan "ilmu atau sains" adalah dua entitas yang tidak dapat dipertemukan. Oleh karena itu perlu dilakukan gerakan rapprochement dan reintegrasi kembali antara agama dan sains, dengan melakukan berbagai macam cara yang antara lain mendirikan lembaga pendidikan yang berorientasi pada penguasaan sains dan teknologi.

Pendidikan dengan model gabungan antara lembaga sekolah dan pesantren dipercaya merupakan jalan untuk mentransformasi gagasan, pemahaman dan kesadaran ini. Oleh karena itu saat ini didirikan SMA Trensains Pesantren Tebuireng Jombang merupakan sintesis dari pesantren dan sekolah umum bidang sains, diproyeksikan untuk mencetak generasi Muslim yang ahli sains dan teknologi. SMA Trensains tidak menggabungkan materi pesantren dan ilmu umum sebagaimana pesantren modern. SMA Trensains mengambil kekhususan pada pemahaman al-Qur'an dan al-Hadits, sains kealaman (natural

\footnotetext{
${ }^{65}$ Abdul Ghofur, "Santri Trensains Membuktikan QS. Yasin [36]: 39 dalam Prespektif Ilmu Pengetahuan”, http://www.smatrensains.sch.id/2015/05/santri-trensains-membuktikan-qs-yasin.html, diakses pada tanggal 24 Agustus 2015.
} 
science) dan interaksinya. Poin terakhir, yaitu interaksi antara agama dan sains merupakan materi khas Trensains.

Trensains tidak melakukan pendekatan dengan hanya melakukan "Islamisasi Sains", yaitu pembeberan ayat-ayat dengan menggunakan sains yang sudah ada, juga tidak melakukan pendekatan dengan cara "Saintifikasi Islam", yaitu hanya berusaha menjelaskan Islam dengan terminologi sains. Akan tetapi Trensains mengajukan pendekatan "Sains Islam" dimana sains dikonstruksi berdasarkan wahyu Allah. Artinya dalam epistemologi Islam, wahyu dan sunah juga dapat dijadikan sebagai sumber inspirasi bagi bangunan ilmu pengetahuan. Dalam tataran ini, epistemologi sains Islam adalah epistemologi sains modern plus atau diperluas, yaitu plus penerimaan wahyu sebagai sumber informasi dan plus metodologi yang tidak tunggal atau kemajemukan metodologi.

Dengan epistemologi sains Islam, sebagaimana yang di terapkan oleh SMA Trensains ini diharapkan khazanah keilmuan terutama sains dan teknologi dalam Islam akan kembali hidup. Ilmu pengetahuan baru yang berlandaskan alQur'an dan Sunah akan semakin banyak bermunculan. Para saintis Muslim akan senantiasa berupaya melakukan penelitian ilmiah dengan tidak meninggalkan kontruksi keilmuannya berlandaskan wahyu Allah. Inilah epistemologi sains Islam yang akan memberikan manfaat kepada umat manusia di dunia, sekaligus akan membawa kemajuan peradaban Islam, sebagaimana yang pernah dicapai umat Islam pada era zaman keemasan Islam.[w] 


\section{BIBLIOGRAPHY}

Abdullah, M. Amin, Islamic Studies di Perguruan Tinggi: Pendekatan IntegratifInterkonektif (Islamic Studies in Higher Education: Integrative-Interconnective Approach), Yogyakarta: Pustaka Pelajar, 2006.

Abdullah, M. Amin, "Etika Tauhidik sebagai Dasar Kesatuan Epistemologi Keilmuan Umum dan Agama: dari Paradigma Positivistik-Sekularistik ke arah Teo-antroposentik-Integralistik)" (Tauhidic Ethics as the Basis for the Epistemology of Unity of Science and Religious Studies - from the Positivisticsecularist Paradigm towards the Theoanthroposentric-integralistic), in M. Amin Abdullah etal, Menyatukan Kembali Ilmu-ilmu Agama dan Umum, Upaya Mempertemukan Epistemologi Islam dan Umum (Reuniting Islamic Studies and Modern Science: the Effort to Unite the Epistemology of Islam and Modern Science), Yogyakarta: Sunan Kalijaga Press, 2003.

Amin, Miska M., Epistemologi Islam (Islamic Epistemology), Jakarta: UI Press, 1983.

al-Attas, Syed M. Naquib, Islam and Scularism, Kuala Lumpur: Angkatan Muda Belia Islam Malaysia, 1978.

al-Attas, Syed M. Naquib, The Concept of Education in Islam, Kuala Lumpur: Angkatan Muda Belia Islam Malaysia, 1980.

al-Attas, Syed M. Naquib, Islam dan Filsafat Pengetahuan (Islam and Philosophy of Science), translated by Saiful Muzani, Bandung: Mizan, 1995.

Ali, Mukti, "Metodologi Ilmu Agama Islam" (Methodology of Islamic Studies), in Taufik Abdullah \& M. Rusli Karim, Metodologi Penelitian Agama: Sebuah Pengantar (Methodology for the Research on Religion: an Introduction), Yogyakarta: Tiara Wacana, 2006.

Arif, Mahmud, "Epistemologi Pendidikan Islam: Kajian Atas Nalar Masa Keemasan Islam dan Aplikasinya di Indonesia" (Epistemology of Islamic Education: a Study on the Logics of Islamic Golden Age and Its Application in Indonesia), Dissertation, Program Pascasarjana UIN Sunan Kalijaga Yogyakarta, 2006.

Arif, Mahmud, Pendidikan Islam Transformatif (Transformative Islamic Education), Yogyakarta: LKiS, 2008. 
Arifin, Imron, Penelitian Kualitatif dalam Bidang Ilmu-ilmu Sosial dan Keagamaan (Qualitative Research in Social Sciences and Religious Studies), Malang: Kalimasada Press, 1994.

Arikunto, Suharsimi, Prosedur Penelitian Suatu Pendekatan Praktek (Research Procedure - a Practical Approach), Jakarta: Bina Aksara, 1997.

Azhar, Muhammad, et.al., Studi Islam dalam Percakapan Epistemologis (Islamic Studies in Epistemological Conversation), Yogyakarta: Sipres, 1998.

Bakri, Masykuri, (ed.), Metodologi Penelitian Kualitatif: Tinjauan Teoritis dan Praktis (Methodology of Qualitative Research: Theoretical and Practical Perspective), Malang: Lembaga Penelitian UM \& Visipress, 2002.

Bagir, Zainal Abidin, et.al., Integrasi Ilmu dan Agama: Interpretasi dan Aksi (Integration of Science and Religion: Interpretation and Action), Bandung: Mizan Pustaka, 2005.

Barbour Ian G, Juru Bicara Tuhan: Antara Sains dan Agama (When Science meets Religion: Enemies, Strangers, or Partners), translated by E. R. Muhammad, Bandung: Mizan, 2002.

Barbour Ian G, Issues in Science and Religion, New York: Harper Tourchbooks, 1996.

Bogdan, Robert C., dan Sari Knopp Biklen, Qualitative Research for Education: An Introduction to Theory and Methods, Boston: Aliyn and Bacon, Inc, 1998.

Bruinessen, Martin van, Kitab Kuning: Pesantren dan Tarekat (Yellow Books. Islamic Boarding School and Sufism), Bandung: Mizan, 1999.

Bucaille, Maurice, Bibel, Qur'an dan Sains (Bible, Quran and Science), translated by A. Rasyidi, Jakarta: Bulan Bintang, 1992.

Bungin, Burhan, Metodologi Penelitian Sosial: Format-format Kuantitatif dan Kualitatif (Methodology of Social Research: Quantitative and Qualitative Formats), Surabaya: Airlangga University Press, 2001.

Departemen Agama RI, al-Qur'an dan Terjemahnya (al-Qur'an and Its Translation), Surabaya: Mekar, 2002.

al-Faruqi, Isma'il Razi, al-Tauhid: Its Implications for Thought and Life, VirginiaUSA: The International Institute of Islamic Thought, 1992.

Furchan, Arief, Pengantar Metode Penelitian Kualitatif (an Introduction to the Method of Qualitative Research), Surabaya: Usaha Nasional, 1992. 
Ghony, M. Djunaidi \& Fauzan Almanshur, Metodologi Penelitian Kualitatif (Methodology of Qualitative Research), Yogyakarta: Ar-Ruzz Media, 2012.

Hadi, Sutrisno, Metodologi Research (Methodology of Research), Yogyakarta: Andi Offset, 1989.

Kaelan, Metode Penelitian Kualitatif Bidang Filsafat (Qualitative Research Method on Philosophy), Yogyakarta: Paradigma, 2005.

Kartanegara, Mulyadhi, Menyibak Teori Kejahilan: Pengantar Epistemologi Islam (Uncover the Theory of Stupidity: an Introduction of Islamic Epistemology), Bandung: Mizan, 2003.

Kuntowijoyo, Islam sebagai Ilmu: Epistemologi, Metodologi dan Etika (Islam as Science: Epistemology, Methodology and Ethics), Yogyakarta: Tiara Wacana, 2006.

Madjid, Nurcholish, Islam: Doktrin dan Peradaban (Islam: Doctrine and Civilization), Jakarta: Paramadina, 1992.

Margono, S., Metodologi Penelitian Pendidikan (Methodology for Research on Education), Jakarta: Rineka Cipta, 2003.

Miles, Matthew B., dan Hubberman, A. Michael, Analisis Data Kualitatif (Analysis of Qualitative Data), translated by Tjetjep Rohendi Rohidi, Jakarta: UI Press, 1992.

Moleong, Lexy J., Metodologi Penelitian Kualitatif (Methodology of Qualitative Research), Jakarta: Remaja Rosdakarya, 1999.

Muqowim, "Genealogi Intelektual Saintis Muslim: Sebuah Kajian tentang Pola Pengembangan Sains dalam Islam pada Periode Abbasiyyah" (Genealogy of Moslem Scientists Intellectual: A Discussion on the Patterns of Science Development in Islam on the Abbasiyah Period), Dissertation, Program Pascasarjana UIN Sunan Kalijaga Yogyakarta, 2011.

Nasr, Seyyed Hossein, Science and Civilization in Islam, New York: New American Library, 1970.

Nasr, Seyyed Hossein, Sains dan Peradaban di dalam Islam (Science and Civilization in Islam), translated by J. Mahyudin, Bandung: Pustaka, 1997.

Polkinghorne, John, Belief in God in an Age of Science, London: Yale University Press, 1988.

Purwanto, Agus, Ayat-ayat Semesta: Sisi al-Qur'an yang Terlupakan (The Verses on Universe: The Forgotten Sides of al-Qur'an), Bandung: Mizan Pustaka, 2013. 
Purwanto, Agus, Nalar Ayat-ayat Semesta (Logics of the Verses on Universe), Bandung: Mizan Pustaka, 2012.

Riyanto, Yatim, Metodologi Penelitian Pendidikan (Methodology of Research on Education), Surabaya: Penerbit SIC, 2001.

Rosadisastra, Andi, Metode Tafsir Ayat-ayat Sains dan Sosial (The Methods of Interpretation on the Scientific and Social Verses), Jakarta: Amzah, 2007.

Saeed, Abdulllah, Pemikiran Islam: Sebuah Pengantar (Islam Thought: an Introduction), Yogyakarta: Baitul Hikmah Press, 2014.

Sardar, Ziauddin, Islamic Futures: the Shapes of Ideas to Come, New York: Mansell, 1985.

Sardar, Ziauddin, Explorations in Islamic Sciences, London-New York: Mansell, 1989.

Stake, Robert E., “Case Studies”, in Norman K. Denzin \& Yvonna S. Lincoln (eds.), Handbook of Qualitative Research, London: Sage Publications, 1994.

Sudarminta, J., Epistemologi Dasar: Pengantar Filsafat Pengetahuan (Basic Epistemology: an Introduction to Philosophy of Science), Yogyakarta: Kanisius, 2002.

Sudjana, Nana \& Ibrahim, Penelitian dan Penilaian Pendidikan (Research and Evaluation on Education ), Bandung: Sinar Baru, 1989.

Suriasumantri, Yuyun, Filsafat Ilmu: Sebuah Pengantar Populer (Philosophy of Science: a Popular Introduction), Jakarta: Sinar Harapan, 1998.

Suparjo, "Komunikasi Interpersonal Kyai-Santri: Studi tentang Keberlangsungan Tradisi Pesantren di Era Modern" (Interpersonal Communication of Kyai-Santri: a Study on the existence of Pesantren Tradition in Modern Era), Dissertation, Program Pascasarjana UIN Sunan Kalijaga Yogyakarta, 2012.

\section{Paper/Journal:}

Acikgenc, Alparslan, "Holisitic Approach to Scientific Traditions, Islam \& Science", Journal of Islamic Perspective on Science, Vol. 1, No. 1, June 2003.

Azhar, Muhammad, "Metode Islamic Studies: Studi Komparatif antara Islamization of Knowledge dan Scientification of Islam" (Method of Islamic Studies: Comparative Study between Islamization of Knowledge and Scientification of Islam), Jurnal Mukaddimah, Vol. XV, No. 26. January-June 2009. 
Assegaf, Abd. Rachman, "Aliran-aliran dalam Pendidikan Islam" (Schools in Islamic Education), Materi Program Pascasarjana Doktor (S3) Kependidikan Islam, UIN Sunan Kalijaga Yogyakarta, 2014.

Ghofur, Abdul, "SMA TRENSAINS Tebuireng adalah Solusi untuk Menjawab Tantangan Global" (TRENSAINS Senior High School is the solution to answer global challenges), document.

Hasan, M. Kamal, "The ExpandingSpiritual-Moral Role of World Religion in the New Millinium", American Journal of Islamic School Science, Volume 18, Number 1., Winter 2001.

Kholil, Mohamad, "Menggagas Pesantren sebagai Pusat Peradaban Muslim di Indonesia" (Discussing about Pesantren as the Center of Moslem Civilization in Indonesia), Jurnal Media Akademika, Vol. 26, No. 3, July 2011.

Nugroho, Wahyu,"Teologi Kristen dalam Konteks Sains: Kajian Kritis atas Gagasan Arthur Peacocke" (Christian Theology in the Context of Science: Critical Discussion on the Ideas of Peacocke Arthur), Journal of Religion Issues, I: 01, 2003.

SMA TRENSAINS Tebuireng Jombang, "TRENSAINS: Jalan Sunyi Pecinta Sains dan al-Qur'an" (TRENSAINS: a Quiet Way of Science and al-Qur'an lovers), document.

Wan Daud, Wan Ramli bin dan Shaharir bin Mohamad Zain, "Pemelayuan, Pemalaysiaan dan Pengislaman Ilmu Sains dan Teknologi dalam Konteks Dasar Sains Negara" (Malaynism, Malaysianism, Islamization of Science and Technology in the basic context of state science), Malay, Jurnal Kesturi, No. 1. 1999.

\section{Internet:}

Ahmar, Fahmi, "Belajar Sains Islam, Bukan Saintifikasi Islam" (Learning Islamic Science, not Islamic Scientification), http://www.globalmuslim.web.id, accessed on August 10th, 2015.

Ghofur, Abdul, "Profil SMA Trensains Tebuireng Jombang” (Profile of Trensains Senior High School, Tebuireng, Jombang), http://www. smatrensains. sch.id/2015/08/profil-sma-trensains-tebuireng.html, accessed on August 15th, 2015.

Ghofur, Abdul, "Santri Trensains Membuktikan QS. Yasin 36: 39 dalam Prespektif Ilmu Pengetahuan" (Trensains Student proving al-Quran Surah 
Yaseen 36: 39 in the Perspective of Science), http://www.smatrensains. sch.id/2015/05/santri-trensains-membuktikan-qs-yasin.html, accessed on August 24th, 2015. 